\title{
HUBUNGAN ANTARA KONSUMSI AIR KELAPA DENGAN PENINGKATAN HEMOGLOBIN (Hb) PADA IBU POST PARTUM DI PUSKESMAS CIKANCUNG
}

\author{
The correlation Between The Consumption Of Coconut Water And \\ The Increase Of Hemoglobin ( $\mathrm{Hb}$ ) In Post Partum Mother \\ In The Puskesmas Cikancung \\ Sri ayu Arianti ${ }^{1}$, Reni Herlina ${ }^{2}$ \\ Universitas Bakti kencana \\ (sri.ayu@bku.ac.id)
}

\begin{abstract}
ABSTRAK
Latar Belakang : Penyebab langsung kematian ibu di Indonesia yaitu akibat perdarahan $28 \%$, eklamsia $24 \%$, dan infeksi $11 \%$. Adapun penyebab tidak langsung kesakitan dan kematian ibu adalah kejadian anemia pada ibu hamil sekitar $50 \%$ dan pada ibu nifas sekitar $49 \%$. Salah satu alternatif untuk meningkatkan hemoglobin yaitu dengan cara mengonsumsi air kelapa.

Tujuan : Tujuan penelitian ini adalah untuk mengetahui hubungan antara konsumsi air kelapa dengan peningkatan hemoglobin $(\mathrm{Hb})$ pada ibu post partum

Metode : Penelitian ini merupakan penelitian Eksperimen Semu (QuasiExperiment). Dalam pelaksanaan penelitian ini menggunakan kelompok kontrol dan kelompok eksperimen. Untuk kelompok kontrol yaitu ibu post partum yang tidak diberi air kelapa dan kelompok eksperimen yaitu ibu post partum yang diberi air kelapa. Populasinya adalah ibu post partum yaitu sebanyak 671 orang. Pengambilan sampel sebanyak 88 orang dengan accidental sampling.

Hasil : Hasil penelitian didapatkan bahwa peningkatan hemoglobin pada ibu post partum yang mengonsumsi air kelapa sebagian besar meningkat yaitu sebanyak $86,4 \%$ (38 orang), peningkatan hemoglobin pada ibu post partum yang tidak mengonsumsi air kelapa sebagian besar tidak meningkat yaitu sebanyak 77,3\% (34 orang), hasil perhitungan Chi Square dengan tingkat kepercayaan 95\% dan tingkat kesalahan 5\%, diketahui tedapat hubungan antara konsumsi air kelapa dengan peningkatan hemoglobin terbukti dengan nilai p-value $(0,000)$ lebih kecil dari nilai $\alpha(0,05)$.
\end{abstract}

Simpulan: Simpulan didapatkan bahwa terdapat hubungan antara konsumsi air kelapa dengan peningkatan hemoglobin.

Kata kunci: Air Kelapa, Hemoglobin. 


\begin{abstract}
Background: The direct causes of maternal mortality in Indonesia are $28 \%$ bleeding, 24\% eclampsia, and $11 \%$ infection. Therefore, the indirect cause of maternal morbidity and mortality is the incidence of anemia in pregnant mother around $50 \%$ and in post-partum mothers around $49 \%$. One of the alternatives to increase the hemoglobin is by consuming coconut water.

The Purpose : The purpose of the research was to determine the correlation between coconut water consumption and the increase of hemoglobin $(\mathrm{Hb})$ in postpartum mothers

Method: The the research was a Quasi-Experiment. The implementation of the research used a control group and an experimental group. The control group was postpartum mothers who were not given coconut water and the experimental group was postpartum mothers who were given coconut water. The population of the research was postpartum mothers (671 mothers). The sampling (88 mothers) taken by accidental sampling.

Result: The results showed that the increase of hemoglobin in postpartum mothers who consumed coconut water was mostly increased as many as $86.4 \%$ (38 mothers), the increase of hemoglobin in postpartum mothers who did not consume coconut water was mostly not increased as many as $77.3 \%$ ( 34 mothers). The results of the Chi Square calculation with a confidence level of $95 \%$ and an error rate of $5 \%$, it is obtained that there is a correlation between coconut water consumption and the increase of hemoglobin. It is showed by the p-value $(0.000)$ which is smaller than the $\alpha$ value $(0.05)$.

Conclusion: The conclusion is that there is a correlation between coconut water consumption and the increase of hemoglobin.
\end{abstract}

Key words: coconut water, hemoglobin

\title{
PENDAHULUAN
}

Angka kematian merupakan salah satu indikator status kesehatan masyarakat. Menurut Data Survey Demografi dan Kesehatan Indonesia (SDKI) tahun 2012, AKI sebesar 359 per 100.000 kelahiran hidup, AKB 32 per 1.000 kelahiran hidup (SDKI. 2012). Penyebab langsung kematian ibu di Indonesia yaitu akibat perdarahan 28\%, eklamsia (24\%), dan infeksi (11\%). Adapun penyebab tidak langsung kesakitan dan kematian ibu adalah kejadian anemia pada ibu hamil sekitar 50\% dan pada ibu nifas sekitar 49\%. Kematian ibu pasca salin atau masa nifas merupakan salah satu penyumbang angka kematian ibu, penyebabnya adalah perdarahan yang tidak tertangani, infeksi, kekurangan energi protein dan komplikasi masa nifas (Prawirohardjo. 2013).

Masa nifas berlangsung selama kira-kira 6-8 minggu, selama waktu tersebut pada seorang ibu nifas seringkali terjadi masalah tanda bahaya masa nifas. Dengan demikian diperlukan pemberian asuhan kebidanan untuk mencegah 
terjadinya masalah pada masa nifas, salah satunya terjadi anemia pada masa nifas (Prawirohardjo. 2013).

Anemia adalah penyakit kurang darah yang ditandai dengan kadar hemoglobin $(\mathrm{Hb})$ dan sel darah merah (eritrosit) lebih rendah dibandingkan normal. Anemia dalam masa nifas merupakan lanjutan daripada anemia yang diderita saat kehamilan, yang menyebabkan banyak keluhan bagi ibu dan mengurangi presentasi kerja, baik dalam pekerjaan rumah sehari-hari maupun dalam merawat bayi (Wijanarko. 2012).

Anemia pada wanita pasca persalinan sering terjadi, sekitar $10 \%$ dan $22 \%$ terjadi pada wanita post partum dari keluarga miskin. Pengaruh anemia pada masa post partum adalah terjadinya subvolusi uteri yang dapat menimbulkan perdarahan post partum, memudahkan infeksi puerperium, pengeluaran ASI berkurang dan mudah terjadi infeksi. Faktor-faktor yang mempengaruhi anemia pada masa post partum adalah persalinan dengan perdarahan, ibu hamil dengan anemia, nutrisi yang kurang, penyakit virus dan bakteri (Prawirohardjo. 2013).

Penyerapan besi juga dipengaruhi oleh adanya zat-zat penghambat penyerapan besi, yaitu asam fitat, asam oksalat, dan tannin yang banyak terdapat pada serealia, sayuran, kacang-kacangan, dan teh. Untuk meningkatkan penyerapan besi, dianjurkan untuk lebih banyak mengkonsumsi vitamin $\mathrm{C}$ dan protein hewani dan juga makanan yang bisa meningkatkan hemoglobin seperti beras merah, buah delima, bayam, alpukat, air kelapa hijau dan sebagainya (Waryana, 2010).

Tanaman kelapa merupakan tanaman yang seluruh bagian dari tanaman bisa dimanfaatkan dalam kehidupan. Bagian dari tanaman kelapa yang sering dimanfaatkan masyarakat luas adalah buahnya yang terdiri dari daging buah dan airnya. Sebagian masyarakat mengkon-sumsi air kelapa hanya dianggap sebagai minuman untuk menghilangkan rasa haus saja, padahal air kelapa memiliki kandungan gizi tinggi seperti mineral, vitamin dan gula serta asam amino esensial yang bermanfaat bagi kesehatan. Kandungan gizi seperti zat besi sebesar 17 ppm atau $2 \mathrm{mg} / 100 \mathrm{~g}$ yang dimiliki air kelapa muda memiliki peranan penting untuk menjaga kesehatan tubuh, salah satunya yang berhubungan dengan hematologi (Aristya. 2012).

Penelitian yang dilakukan oleh Qorina Sabila mengenai perbedaan kadar hemoglobin (hb) dalam darah sebelum dan sesudah konsumsi air kelapa hijau (Green Coconut Water) pada pekerja yang terpapar timbal $(\mathrm{Pb})$ di Karoseri $\mathrm{X}$ Semarang didapatkan hasil bahwa kadar hemoglobin sesudah konsumsi air kelapa hijau terjadi peningkatan rata-rata sebanyak 0,30 gr/dl dan terdapat hubungan antara kadar $\mathrm{Hb}$ dalam darah sebelum dan sesudah konsumsi air kelapa (Sabila, Qorina. 2016).

Berdasarkan data dari Dinas Kesehatan Kabupaten Bandung didapatkan data bahwa kejadian anemia pada ibu post partum terbanyak yaitu di Puskesmas Cikancung sebanyak 36 orang (13,69\%), data pembanding di Puskesmas Nagreg didapatkan bahwa kejadian anemia pada ibu post partum sebanyak 28 orang $(10,64 \%)$. 


\section{METODE PENELITIAN}

Rancangan penelitian yang digunakan pada penelitian ini adalah Eksperimen Semu (Quasi-Experiment), penelitian yang berupaya mengungkapkan hubungan sebab akibat. Dalam pelaksanaan penelitian ini menggunakan kelompok kontrol dan kelompok eksperimen. Untuk kelompok kontrol yaitu ibu post partum yang tidak diberi air kelapa dan kelompok eksperimen yaitu ibu post partum yang diberi air kelapa.

Populasi dalam penelitian ini adalah ibu post partum di wilayah kerja Puskesmas Cikancung yaitu sebanyak 671 orang.Sampel yang digunakan yaitu 88 orang dengan dibagi 2 yaitu 44 orang ibu post partum yang diberi air kelapa dan 44 orang ibu post partum yang tidak diberi air kelapa. Teknik sampling yang digunakan dalam penelitian ini yaitu accidental sampling.

\section{HASIL DAN PEMBAHASAN}

\section{Hasil}

Tabel 1 Distribusi Frekuensi Peningkatan Hemoglobin (Hb) pada Ibu Post partum yang Mengonsumsi Air Kelapa di Wilayah Kerja Puskesmas Cikancung Kabupaten Bandung

\begin{tabular}{clcc}
\hline No. & Peningkatan Hemoglobin & Jumlah & Persentase (\%) \\
\hline 1 & Meningkat & 38 & 86,4 \\
2 & Tidak meningkat & 6 & 13,6 \\
\hline \multicolumn{2}{r}{ Total } & $\mathbf{4 4}$ & $\mathbf{1 0 0}$ \\
\hline
\end{tabular}

Berdasarkan tabel 1 diketahui bahwa peningkatan hemoglobin pada ibu post partum yang mengonsumsi air kelapa sebagian besar meningkat yaitu sebanyak $86,4 \%$ (38 orang) dan sebagian kecil tidak meningkat yaitu sebanyak 13,6\% (6 orang).

Tabel 2 Distribusi Frekuensi Peningkatan Hemoglobin (Hb) pada Ibu Post partum yang Tidak Mengonsumsi Air Kelapa di Wilayah Kerja Puskesmas Cikancung Kabupaten Bandung

\begin{tabular}{clcc}
\hline No. & Peningkatan Hemoglobin & Jumlah & Persentase (\%) \\
\hline 1 & Meningkat & 10 & 22,7 \\
2 & Tidak meningkat & 34 & 77,3 \\
\hline \multicolumn{2}{r}{ Total } & $\mathbf{4 4}$ & $\mathbf{1 0 0}$ \\
\hline
\end{tabular}


Berdasarkan tabel 2 diketahui bahwa peningkatan hemoglobin pada ibu post partum yang tidak mengonsumsi air kelapa sebagian besar tidak meningkat yaitu sebanyak 77,3\% (34 orang) dan sebagian kecil meningkat yaitu sebanyak $22,7 \%$ (10 orang).

Tabel 3 Hubungan antara Konsumsi Air Kelapa dengan Peningkatan Hemoglobin (Hb) pada Ibu Post partum di Wilayah Kerja Puskesmas Cikancung Kabupaten Bandung

\begin{tabular}{|c|c|c|c|c|c|c|c|}
\hline \multirow{3}{*}{$\begin{array}{c}\text { Konsumsi Air } \\
\text { Kelapa }\end{array}$} & \multicolumn{4}{|c|}{ Peningkatan $\mathrm{Hb}$} & \multirow{2}{*}{\multicolumn{2}{|c|}{ Total }} & \multirow{3}{*}{$p$-value } \\
\hline & \multicolumn{2}{|c|}{ Meningkat } & \multicolumn{2}{|c|}{ Tidak meningkat } & & & \\
\hline & f & $\%$ & f & $\%$ & f & $\%$ & \\
\hline Ya & 38 & 86,4 & 6 & 13,6 & 44 & 100 & \multirow{3}{*}{0,000} \\
\hline Tidak & 10 & 22,7 & 34 & 77,3 & 44 & 100 & \\
\hline Total & 48 & 54,5 & 40 & 45,5 & 88 & 100 & \\
\hline
\end{tabular}

Berdasarkan tabel 3 hasil analisis tabel silang antara konsumsi air kelapa dengan peningkatan hemoglobin didapatkan responden yang mengonsumsi air kelapa sebagian besar hemoglobinnya meningkat yaitu sebanyak 86,4\% (38 orang) dan responden yang tidak mengonsumsi air kelapa sebagian besar hemoglobinnya tidak meningkat $77,3 \%$ (34 orang).

Dari hasil perhitungan Chi Square dengan tingkat kepercayaan 95\% dan tingkat kesalahan 5\%, diketahui bahwa nilai $p$-value $(0,000)$ lebih kecil dari nilai $\alpha(0,05)$, sehingga dapat disimpulkan bahwa terdapat hubungan antara konsumsi air kelapa dengan peningkatan hemoglobin.

\section{Pembahasan}

\section{Gambaran Peningkatan Hemoglobin (Hb) pada Ibu Post Partum yang Mengonsumsi Air Kelapa}

Air kelapa mengandung sejumlah zat besi $0,2 \%$, protein $0,2 \%$, lemak $0,15 \%$, karbohidrat $7,27 \%$, gula, vitamin, elektrolit dan hormon pertumbuhan. Kandungan gula maksimun 3 gram per $100 \mathrm{ml}$ air kelapa. Jenis gula yang terkandung adalah sukrosa, glukosa, fruktosa dan sorbitol. Berbagai sumber zat Fe yang ada di alam salah satunya yaitu dari air air kelapa, kandungan zat Fe dari air kelapa sebanyak $2 \mathrm{mg} / 100$ gram. Dari kandungan Fe tersebut maka dapat dipastikan apabila dikonsumsi bisa meningkatkan kadar hemoglobin (Surya. 2013).

Berdasarkan teori di atas, dilihat dari kandungan tersebut maka air kelapa memiliki zat besi sebanyak 0,2\%. Dengan kandungan tersebut maka air kelapa apabila dikonsumsi secara teratur makan bisa memberikan kebutuhan zat besi pada tubuh. Hasil penelitian menunjukkan sebagian besar kadar hemoglobin pada ibu post partum meningkat $(86,4 \%)$ hal ini dikarenakan ibu tersebut mengonsumsi air kelapa. Sedangkan sebagian kecil tidak meningkat $(13,6 \%)$ hal ini dikarenakan ibu yang beraktivitas lebih berat memungkinkan kebutuhan zat besi lebih banyak 
sehingga walaupun ibu menerima asupan zat besi namun ibu tetap saja kekurangan zat besi.

\section{Gambaran Peningkatan Hemoglobin (Hb) pada Ibu Post Partum yang Tidak Mengonsumsi Air Kelapa}

Hemoglobin adalah protein yang kaya akan zat besi. Ia memiliki afinitas (daya gabung) terhadap oksigen dan dengan oksigen itu membentuk oxihemoglobin di dalam sel darah merah. Dengan melalui fungsi ini maka oksigen di bawa dari paru-paru ke jaringan-jaringan (Evelyn . 2010).

Hasil penelitian menunjukkan bahwa kadar hemoglobin pada ibu post partum sebagian besar tidak meningkat $(77,3 \%)$ hal ini dikarenakan ibu post partum dalam kelompok ini tidak diberi air kelapa. Sedangkan sebagian kecil meningkat $(22,7 \%)$ hal ini dikarenakan selain air kelapa banyak cara lain untuk meningkatkan hemoglobin seperti mengkonsumsi tambahan kalori, istirahat yang cukup, pemberian tablet $\mathrm{Fe}$ dan transfusi darah (bagi yang mengalami anemia berat).

\section{Hubungan antara Konsumsi Air Kelapa dengan Peningkatan Hemoglobin (Hb) pada Ibu Post Partum}

Ibu post partum membutuhkan zat besi (Fe) untuk meningkatkan kadar $\mathrm{Hb}$ yang dapat mencegah terjadinya anemia. Salah satu upaya dalam meningkatkan kadar $\mathrm{Hb}$ yaitu dengan mengkonsumsi air kelapa. Air kelapa mengandung protein, zat besi, asam folat dan vitamin $\mathrm{C}$ yang diperlukan dalam pembentukan sel darah merah (Surya. 2013).

Sebagian masyarakat mengkonsumsi air kelapa hanya dianggap sebagai minuman untuk menghilangkan rasa haus saja, padahal air kelapa memiliki kandungan gizi tinggi seperti mineral, vitamin dan gula serta asam amino esensial yang bermanfaat bagi kesehatan. Kandungan gizi yang dimiliki air kelapa muda memiliki peranan penting untuk menjaga kesehatan tubuh, salah satunya yang berhubungan dengan hematologi (Sabila, Qorina. 2016).

Responden yang mengonsumsi air kelapa sebagian besar meningkat $(86,4 \%)$ hal ini dikarenakan adanya asupan makanan yang mengandung zat besi yaitu air kelapa. Sedangkan responden yang tidak diberi air kelapa sebagian besar tidak meningkat $(77,3 \%)$. Hal ini dikarenakan kurangnya asupan zat besi yang diterima oleh ibu post partum.

Keadaan ibu yang mengonsumsi zat besi dengan hasil ada kadar hemoglobin yang tidak meningkat sebanyak 6 orang $(13,6 \%)$. dikarenakan hasil wawancara didapatkan mereka jarang istrahat tidur, setiap malam sering terbangun setidaknya 1 jam sekali harus bangun karena bayi menangis.

Air kelapa mengandung sejumlah zat besi $0,2 \%$, protein $0,2 \%$, dari kandungan $\mathrm{Fe}$ dan protein tersebut maka dapat dipastikan apabila dikonsumsi bisa meningkatkan kadar hemoglobin (Surya. 2013). Haemoglobin memiliki afinitas (daya gabung) terhadap oksigen dan dengan oksigen itu membentuk oxihemoglobin di dalam sel darah merah. Dengan melalui fungsi ini maka oksigen di bawa dari paru-paru ke jaringan-jaringan tubuh (Evelyn . 2010). Jaringan tubuh 
dalam uterus mengakibatkan terjadinya kontraksi uterus, hal ini akan mengakibatkan tidak terjadi perdarahan post partum, sehingga ibu tidak terjadi anemia.

Keadaan ibu yang tidak mengonsumsi zat besi dengan hasil terdapat kadar hemoglobin yang meningkatkan sebanyak 10 orang $(22,7 \%)$. Hasil wawancara terhadap 10 orang ibu tersebut, didapatkan bahwa mereka selalu makan yang lebih banyak dari biasanya dan makanan yang bergizi tinggi seperti daging sapi yang mengandung banyak kalori, protein dan zat besi, sayuran seperti bayam dan brokoli yang mengandung zat besi serta buah-buahan yang mengandung vitamin dan mineral termasuk zat besi. Selain dari itu ibu juga berusaha untuk istirahat dengan cukup karena bayi bisa dijaga oleh keluarga.

\section{SIMPULAN DAN SARAN}

\section{Simpulan}

Simpulan dalam penelitian ini sebagian besar ibu post partum yang mengonsumsi air kelapa terdapat peningkatan hemoglobin yaitu sebanyak $86,4 \%$ (38 orang) sedangkan pada ibu post partum yang tidak mengonsumsi air kelapa sebagian besar tidak terjadi peningkatan hemoglobin yaitu sebanyak 77,3\% (34 orang) sehingga dapat disimpulkan bahwa terdapat hubungan antara konsumsi air kelapa dengan peningkatan hemoglobin dengan p-value $(0,000)$ lebih kecil dari nilai $\alpha(0,05)$.

\section{Saran}

Diharapkan bagi peneliti selanjutnya dapat menjadi bahan acuan dalam meneliti lebih lanjut mengenai cara meningkatkan hemoglobin pada ibu post partum bisa menggunakan berbagai macam alternatif makanan.

\section{DAFTAR PUSTAKA}

Aristya. 2012. Kajian Aspek Budidaya Dan Keragaman Morfologi Tanaman Kelapa (Cocos nucifera L.) di Kabupaten Kebumen. Dikutip dari http://jurnal.ugm.ac.id/jbp/article/view/1606. Diakses tanggal 28 november 2014

Evelyn . 2010. Anatomi dan Fisiologi untuk Paramedis. Jakarta: Gramedia

Prawirohardjo. 2013. Buku Acuan Nasional Pelayanan Kesehatan Maternal Dan Neonatal. Jakarta :Yayan Bina Pustaka

Sabila, Qorina. 2016. Perbedaan Kadar Hemoglobin (Hb) dalam Darah Sebelum dan Sesudah Konsumsi Air Kelapa Hijau (Green Coconut Water) Pada Pekerja yang Terpapar Timbal (Pb) Di Karoseri X Semarang. Jurnal Kesehatan Masyarakat Universitas Diponegoro.

SDKI. 2012. Survei Demografi dan Kesehatan Indonesia Tahun 2012. Jakarta: Badan Kependudukan dan Keluarga Berencana Nasional.

Surya. 2013. Ilmu Gizi untuk Mahasiswa dan Profesi di Indonesia Jilid I. Jakarta: Penerbit Dian Rakyat 
Avicenna : Journal of Health Research, Vol 3 No 2. Oktober 2020 (25 - 32)

Sri ayu Arianti, Reni Herlina (Hubungan Antara Konsumsi Air Kelapa Dengan Peningkatan Hemoglobin (Hb) Pada Ibu Post Partum Di Puskesmas Cikancung)

Waryana, 2010. Gizi Reproduksi. Yogyakarta: Pustaka Rihama

Wijanarko. 2012." Hubungan Anemia dengan Pengetahuan Gizi, Konsumsi Fe, Protein, Vitamin C, dan Pola Haid pada Mahasiswa Putri” dalam Media Gizi Mikro Indonesia : Indonesia Journal of Micronutrient, Vol 4, no 1. Magelang, Jawa Tengah: Balai Penelitian dan Pengembangan kesehatan 